\section{Mike Mills-Davies}

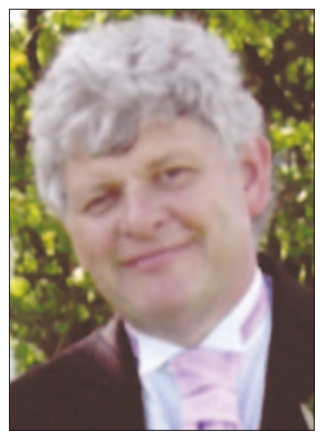

Mike Mills-Davies passed away suddenly on 26 August 2006 aged 58 years.

Educated at Dynevor School in Swansea, Mike qualified in 1972 in Cardiff. Following an associateship in Tirduenaw in Swansea, Mike bought a practice in Clydach in the lower Swansea Valley. He worked there for more than 30 years and also ran a second practice in Pontardawe during that time. He was an enthusiastic GDP, loved his chosen profession and cared for his patients with immense dedication. He developed an interest in orthodontics through clinical attachments at the Orthodontic Department at Morriston Hospital.

Mike worked tirelessly for the profession in South-West Wales. He became a member of West Glamorgan Local Dental Committee in 1978 and was its Chairman for 10 years from 1988 until 1998. He was a member of the West Glamorgan FPC and subsequently the West Glamorgan FHSA. He represented the LDC on the West Glamorgan Dental Advisory Committee and latterly on the Morgannwg District Dental Committee. He attended numerous LDC Conferences and always spoke with passion, wit and eloquence.

During his chairmanship of the LDC Mike oversaw the start of the new contract in the early 1990s. He was a major player in setting up the Out of Hours service in the area. He was proud of the structure of

\section{Mike was a larger than life character with a wicked sense of humour.}

the service and always referred to it as a 'Rolls-Royce Service'.

Mike became the first dental member of Neath Port Talbot LHB and was its first Clinical Governance Lead. He was well respected in LHB circles and this has contributed in no small measure to the excellent relationship that exists between that LHB and the profession locally.

Mike was a larger than life character with a wicked sense of humour. Those who knew him were always struck by his optimistic approach to everything that was put before him, particularly when his clinical career was cut short in 1999 following an horrific accidental eye injury and further to that in 2004 when he was diagnosed with a malignant tumour. He bore the subsequent surgery and numerous chemotherapy treatments without complaint and with unbelievable optimism until his final days.

Despite all this Mike's passing was nevertheless sudden. He was, despite his devotion of time to the profession, a loving and proud husband and father and a devoted family man. Our thoughts are with Lesley and his family and it is to them that we extend our deepest sympathies.

Roger Pratley

\section{Paul Anthony 0’Prey}

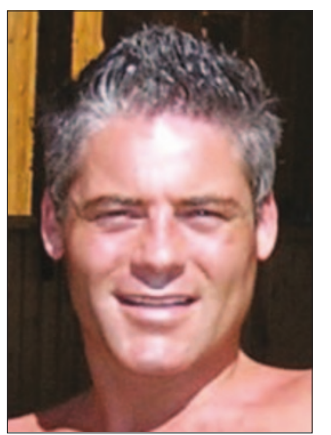

On Wednesday 23 August 2006, Paul 0'Prey was involved in a tragic road accident and was killed instantly. He was 35 years old.

Paul (Pop) graduated from Manchester in 1993 before returning to Ireland. He worked in general practice first in Belfast and then in Downpatrick, where he remained until his untimely death.

Paul grew up in Warrenpoint, Co. Down and there he spent the last decade of his life. He was educated at The Abbey Grammar in Newry, where he shone, both academically and on the sports field. In his final year he won the prize for the most outstanding athlete and represented the college in Gaelic football, captained his local club, and represented Co. Down at underage level. At that time, Paul was widely regarded as being one of the most gifted Gaelic footballers in Ulster. He also had a brilliant brain. I have been privileged to teach dental students for almost a decade, and with due respect to all I taught, I have not encountered another with a brain like Paul's. He was a genius in the truest sense of the word.

Warrenpoint was the only place where Paul really wanted to be. He led an exceptionally active and healthy life, spending every weekend walking in the hills beyond Warrenpoint and swimming daily in Carlingford Lough, where the indigenous sea lions got so used to his intrusion that they'd swim with him. On his daily excursions he'd always have time to stop for a chat with the locals, who knew him well. Paul's death leaves a great sadness and loss to the town.

Pop was a big man in every way: in personality, build, enter-

\section{I have not encountered another with a}

\section{brain like Paul's. He was a genius in the truest sense of the word.}

tainment and competition. Whatever he did, he wanted to be the best and normally succeeded. Talent came naturally to Paul. He could play football as well with either foot, write and drill as well with either hand. He was the big personality, the comedian and the life and soul of the Class of ' 93.

Another of Paul's qualities was a loyalty to the underdog. His staff recount many tales of his generosity to those he deemed to be less fortunate. This unique quality is reflected in the many letters received, telling of his generosity and kindness.

I had the privilege of sharing digs with Paul for his student days. I'll remember Paul, during those formative years, for his loyalty, generosity, friendship and most of all, for the laughter. Pop didn't perform even the most simple of tasks without having all around him in stitches. Living with him was a real-life sitcom.

His patients, colleagues, classmates, friends and staff sorely miss Paul. The people hurting most however, are his loved ones: his father John, mother Margaret, his brothers John, Karl and Kevin, his girlfriend Michelle and his close family members. The 0'Preys still mourn the loss of Paul's brother Patrick in 1987, just 14 years old at the time.

Pop, you'll never be forgotten - your memory lives forever. With deep sadness, your old sparring partner - McFergo.

Johnny Fearon 